\title{
Komunikasi budaya masyarakat Pandai Sikek dalam melakukan transformasi pengetahuan lokal
}

\author{
Elfitri Kurnia Erza1, Pawit M. Yusup ${ }^{2}$, Wina Erwina ${ }^{3}$ \\ ${ }^{1}$ Program Studi Ilmu Perpustakaan Universitas YARSI \\ Menara YARSI Kav. 13, Jl. Letjen. Suprapto, Jakarta 10410 \\ 2,3Program Studi Ilmu Perpustakaan Universitas Padjadjaran \\ Jl. Raya Bandung-Sumedang Km. 21, Jatinangor, Sumedang, Jawa Barat 45363 \\ E-mail: ${ }^{1}$ elfitri.kurnia@yarsi.ac.id, ${ }^{2}$ pawit.m.yusup@unpad.ac.id, ${ }^{3}$ wina.erwina@unpad.ac.id
}

Received: January 2017; Accepted: April 2018; Published: May 2018

\begin{abstract}
The 'Pandai Sikek' weaving activity is a form of cultural communication through the maternal line (matrilineality) which upholds values and norms. Values and norms of the 'songket' culture are governed by the people's belief that there was an ancestral sacred oath. The local people make information fosters the development of knowledge. This promotes the transformation of knowledge as a form of local knowledge development of the Pandai Sikek community which is fully supported by the community and by the use of media as well. The purpose of this study was to look at the communication pattern of the weaver, employer and government in the transformation process of local knowledge. The research method used was qualitative with ethnographic approach. The main data were collected by unstructured interview, observation and documentation study. The communication pattern among weavers was circular, involving experience, information sharing, application, knowledge, and innovation. Study results indicated the existence of a pattern by the weaver's community, were experiences shared through information sharing, and then applied to create knowledge. The use of knowledge would result in innovation and then became an experience again. Entrepreneurs became the bridge for cooperation to support the economy of society. The government issued a policy of protection and knowledge preservation through HAKI (Intellectual Property Rights). In conclusion, the transformation of knowledge continues to develop the socio-economic life of society containing values, norms, and beliefs, which has been performed from generation to generation.
\end{abstract}

Keywords: Weaving; Culture; Local knowledge; Knowledge transformation

\begin{abstract}
Abstrak
Kegiatan menenun Pandai Sikek merupakan bentuk komunikasi budaya dari garis ibu atau matrilineal yang memiliki nilai dan norma. Nilai dan norma mengenai budaya songket diatur kepercayaan masyarakat bahwa adanya sumpah sati nek moyang (sumpah sakti nenek moyang). Masyarakat lokal menjadikan informasi sebagai pendukung perkembangan pengetahuan. Hal ini yang mendorong terjadinya transformasi pengetahuan sebagai bentuk adanya pengembangan pengetahuan lokal masyarakat Pandai Sikek dengan banyaknya dorongan sosial, masyarakat serta adanya penggunaan media. Tujuan penelitian melihat pola komunikasi penenun, pengusaha dan pemerintah dalam proses transformasi pengetahuan lokal. Subjek penelitian adalah penenun, pengusaha dan pemerintahan Pandai Sikek. Metode penelitian yang digunakan adalah kualitatif dengan pendekatan etnografi. Pengumpulan data utama dilakukan dengan wawancara tidak terstuktur, observasi, serta studi dokumentasi. Pola komunikasi antar penenun bersifat melingkar di mana melibatkan pengalaman, berbagi informasi, aplikasi, pengetahuan hingga menjadi inovasi. Hasil penelitian menunjukkan bahwa pola yang dilakukan masyarakat penenun yaitu pengalaman yang dibagi melalui sharing information, kemudian diaplikasikan menjadi pengetahuan. Penggunaan pengetahuan akan menghasilkan inovasi kemudian menjadi pengalaman kembali. Pengusaha menjadi jembatan kerja sama untuk mendukung ekonomi masyarakat. Pemerintah mengeluarkan kebijakan perlindungan dan pelestarian pengetahuan melalui Hak Kekayaan Intelektual (HAKI). Transformasi pengetahuan tetap dilakukan untuk mengembangkan
\end{abstract}


kehidupan sosial ekonomi masyarakat yang mengandung nilai, norma, kepercayaan serta dilakukan secara turun menurun.

Kata Kunci: Tenun; Budaya; Pengetahuan lokal; Transformasi pengetahuan

\section{PENDAHULUAN}

Pandai Sikek adalah salah satu dari dua daerah penghasil songket di Sumatera Barat selain Silungkang. Songket merupakan hasil tenun yang menggunakan benang emas. Pembuatan songket pada dasarnya di setiap daerah Sumatera Barat menggunakan bahan dan alat yang sama. Pada budaya tenun Pandai Sikek dikenal istilah sumpah sati nek moyang, sumpah nenek moyang mengatur pola pewarisan pengetahuan mengenai songket. Kepercayaan mereka mengatakan bahwa terdapat sumpah nenek moyang yang mengatur bahwa orang yang boleh belajar, mengajar dan membuat songket adalah orang asli keturunan Pandai Sikek jika ditarik garis ibu atau disebut matrilineal. Hal ini menunjukkan bahwa yang terlibat dalam pembuatan songket baik sebagai penenun dan pengusaha songket harus keturunan Pandai Sikek. Pandai Sikek menjadikan masyarakatnya memiliki tanggung jawab baik pada dirinya sendiri maupun pada budaya yang telah mengikat mereka dalam satu aturan budaya sehingga mereka harus mematuhinya. Kegiatan menenun di Pandai Sikek menjadi gambar pada uang kertas pecahan Rp. 5000,00 yang dikeluarkan pada tahun 2004. Gambar tersebut memperlihatkan seorang wanita menggunakan pakaian adat Minangkabau dalam bentuk tingkuluak tanduak sedang menenun dengan menggunakan alat tenun yang dinamakan panta.

Pengetahuan lokal yang dimiliki masyarakat Pandai Sikek merupakan aset lokal yang tidak terlihat (intangible asset) dimiliki oleh suatu masyarakat. Hasil tenun yang dibuat dengan pengetahuan masyarakat lokal merupakan ekspresi budaya tradisional (WIPO, 2014). Adanya songket Pandai Sikek dibuat dengan motif yang merupakan ekspresi dari hamparan alam dan budaya masyarakat Minangkabau yang ada di daerah Pandai Sikek. Pengetahuan dalam membuat songket secara umum dimiliki beberapa daerah di Indonesia, namun di Pandai Sikek pengetahuan ini tidak hanya menjadi keterampilan tapi juga sebagai budaya masyarakat. Terutama dalam hal transfer pengetahuan songket ini masyarakat masih menjadikan kaum wanita sebagai pemilik pengetahuan, di mana dalam mengajarkan anak tenun dalam belajar harus menyediakan saripati. Saripati merupakan suatu hantaran yang disediakan oleh anak tenun kepada orang yang mengajarkannya, namun hantaran ini tidak dapat digunakan pengajar sampai anak tenun ini benar-benar dapat menghasilkan satu songket yang dibuat oleh tangannya sendiri. Persyaratan ini bersifat mutlak di mana semua anak tenun yang ingin belajar harus memberikan syarat sebagai permintaan ketulusan untuk mendapatkan pengetahuan.

Berdasarkan hasil penelitian sebelumnya terdapat beberapa aturan dalam transfer pengetahuan yang sudah mengalami perubahan (Erza, 2014). Pertama, saripati, yakni syarat untuk belajar menyongket, yang terdiri dari beras 2,5 kg., sirih, buah pinang kering, sirih kapur, gambir, rokok sebungkus (bila pengajar tidak merokok dapat diberikan 
sebatang rokok saja), buah gambri kering satu buah, bunga saripati beberapa helai, dan uang seharga emas atau sesuai kesepakatan pengajar dengan murid. Ternyata hal ini tidak lagi menjadi sesuatu yang wajib diberikan anak tenun kepada pengajarnya. Terutama saripati dari anak sebagai anak tenun dan ibu kandung sebagai pengajar. Namun, masih digunakan jika yang menjadi pengajarnya bukan ibu kandung (seperti bibi, nenek dsb). Kedua, adanya adaptasi motif dari berbagai sumber sebagai bentuk kreasi dan inovasi. Ragam motif ini mulai digunakan untuk mengembangkan motif yang sudah ada, terutama untuk motif yang mudah dibuat sehingga harganya pun akan jauh di bawah harga songket bermotif klasik. Ketiga, adanya media komunikasi dan media penyimpanan yang digunakan transfer pengetahuan sesama penenun.

Selain itu adanya pola pewarisan serta pengetahuan yang tersimpan dalam bentuk tacit (dalam pikiran) saja membuat pengetahuan mengenai pembuatan songket ini rentan akan kepunahan. Pengetahuan dapat saja hilang jika pemilik pengetahuan meninggal atau pindah dari Pandai Sikek tanpa adanya pewarisan yang berkelanjutan. Eksistensi pengetahuan lokal ditentukan oleh sistem pewarisan yang dilakukan secara lisan oleh masyarakat lokal. Pada zaman dahulu sumber informasi utama adalah Datuak yang merupakan pemimpin adat, yang berfungsi mengambil kebijakan, memastikan nilai dan norma berjalan sesuai dengan fungsinya serta berbagai aturan lain yang dijadikan pedoman bagi masyarakat Pandai Sikek dalam mengelola pengetahuan lokal yang mereka miliki. Hal yang berbeda dapat ditemui sekarang. Masyarakat Pandai Sikek mulai dari usia tua sebagai pemilik pengetahuan hingga generasi muda akan menjadi pemilik pengetahuan yang terpapar arus teknologi informasi. Setiap keluarga dalam masyarakat dapat menerima informasi melalui teknologi informasi dan komunikasi. Hal ini mengakibatkan pengetahuan yang dulunya diturunkan secara turun menurun dengan sistem pewarisan serta konten pesan yang sama dapat berubah. Perubahan inilah yang kemudian dinamakan transformasi pengetahuan. Perubahan dapat terjadi dalam keadaan sadar maupun tidak serta perubahan yang mengakibatkan pengurangan atau pengembangan pengetahuan lokal masyarakat. Pada proses ini terjadi peralihan dari masyarakat lokal yang konservatif menjadi masyarakat informasi (yang berbasis lokal). Adapun beberapa faktor yang mengindikasikan terjadinya masyarakat informasi dalam konteks multidisciplinary informasi (Nath, 2009), seperti berikut: (1) Teknologi. Adanya kontak yang dilakukan masyarakat dalam mengupayakan dan mengembangkan teknologi. Adanya teknologi dalam memengaruhi keberadaan masyarakat informasi. (2) Ekonomi. Kehidupan masyarakat selalu berkaitan dengan ekonomi. Faktor ekonomi membuat informasi semakin berkembang dikarenakan pemenuhan kebutuhan hidup oleh masyarakat. (3) Occupational (pekerjaan). Pemenuhan kebutuhan hidup selalu dikaitkan dengan pekerjaan. Informasi menjadi kebutuhan dalam pekerjaan masyarakat informasi sehingga informasi terlibat dalam kegiatan kerja masyarakat. (4) Spasial. Masyarakat informasi secara geografi biasanya tersebar pada berbagai daerah, sehingga mereka memerlukan jaringan informasi yang dapat menghubungkan lokasi dan 
pencapaian kerja sama. Peran informasi menjadi penting untuk kepentingan interaksi dan jejaring komunikasi. (5) Budaya. Adanya budaya kontemporer yang mengisyaratkan bahwa interaksi berkaitan dengan pertukaran, penerimaan, serta penolakan informasi dalam masyarakat. Masyarakat memiliki hak untuk memilih, menggunakan dan mempresentasikan informasi sesuai dengan kebutuhan. Namun, keberadaan budaya kontemporer selalu berubah karena arus informasi.

Pada teori interaksi simbolis terdapat tiga unsur pokok yaitu pikiran (mind), diri (self) dan masyarakat (society). Dalam proses komunikasi yang terjadi selama terjadinya transformasi pengetahuan mengenai budaya tenun songket melibatkan interaksi yang sesuai dengan teori interaksi simbolis. Pada tahapan pertama sebagai individu yang ada dalam masyarakat memiliki nilai budaya dalam menjadikan budaya songket sebagai identitas bagi mereka. Tercipta kepercayaan yang bertujuan untuk melindungi pengetahuan baik secara sosial maupun ekonomi. Pada unsur self, terlihat dari sikap mereka dalam menunjukkan identitas dengan menjadikan Pandai Sikek sebagai desa wisata yang memiliki kepercayaan menjaga apa yang diberikan leluhurnya dengan tidak mengajarkan teknik membuat songket pada orang lain. Hal ini yang kemudian membuat masyarakat memercayai apa yang mereka miliki, dan kemudian mengembangkannya agar tidak terjadi kepunahan.

Pengetahuan lokal memiliki ciri yang sangat spesifik yaitu disampaikan secara lisan dari generasi ke generasi. Dalam penurunan pengetahuan generasi yang akan menerimanya terus menyesuaikan dengan keadaan lingkungan. Begitu juga dengan penurunan pengetahuan pada masyarakat Pandai Sikek. Komunikasi yang dilakukan secara oral tradition oleh masyarakat Pandai Sikek mengenai pengetahuan mereka merupakan hal yang rentan akan perubahan. Proses transfer yang dilakukan secara lisan juga bisa mengakibatkan distorsi pengetahuan (Primadesi, 2013). Ketika masyarakat Pandai Sikek saling bertukar pikiran mengenai pengetahuan mereka baik untuk meningkatkan kualitas, kreasi motif atau pemberdayaan yang dilakukan pemerintah dilakukan secara langsung tanpa ada dokumentasi. Pengetahuan yang ditukarkan dapat saja menciptakan pengetahuan baru atau mengembangkan pengetahuan yang sebelumnya. Kemudian pengetahuan yang sudah dipaketkan dan dipercaya akan menyebar dengan sendirinya pada masyarakat lainnya karena sistem oral tradition lebih menekankan pada interaksi yang dilakukan masyarakat lokal. Hal inilah yang kemudian menjadi faktor pendorong terjadinya transformasi pengetahuan pada masyarakat. Sedangkan pengetahuan adalah informasi yang sudah diolah, hasil pikir manusia, pengalaman serta pembelajaran yang diinternalisasi menjadi milik sendiri. Transformasi pengetahuan terjadi karena peralihan orientasi yang khas dan historis. Adanya transformasi pengetahuan merupakan perubahan yang terjadi pada hasil olah pikir manusia yang disebabkan oleh adanya pengalaman serta faktor eksternal lainnya sehingga pengetahuan yang sudah ada mengalami penambahan, pengurangan, modifikasi dan perubahan pada konten pengetahuan. Untuk itu pada penelitian ini akan dibahas mengenai peran serta komunikasi 
masyarakat antara penenun dengan penenun, penenun dengan pengusaha dan penenun dengan pemerintah dalam melakukan transformasi pengetahuan lokal masyarakat Pandai Sikek.

\section{METODE PENELITIAN}

Dalam upaya mengungkap realitas di lapangan, penelitian ini menggunakan metode kualitatif. Penelitian ini bermaksud untuk mengungkap realitas dengan menganalisis masyarakat secara alami. Penelitian kualitatif berangkat dari fenomena yang ada di lapangan, yang kemudian penulis membahas dari segi komunikasi melalui teori-teori komunikasi yang ada. Penelitian ini merupakan penelitian etnografi. Menurut Creswell dan Poth (2012), "Ethnography is qualitative design in which the researcher describe and interprets the shared and learned pattern of values, behavior, belief and language of a culture-sharing group". Pendekatan etnografi digunakan untuk melihat suatu budaya secara utuh melewati semua aspek budaya yang bersifat terlihat berupa dokumen dan artefak budaya serta tidak terlihat seperti pengalaman, norma dan sistem nilai kelompok.

Subjek penelitian adalah masyarakat Pandai Sikek yang dibagi menjadi penenun, pengusaha dan pemerintahan. Objek penelitian adalah proses komunikasi yang dilakukan masyarakat Pandai Sikek dalam melakukan transformasi pengetahuan. Penelitian dilakukan di Nagari Pandai Sikek pada tahun 2015. Pengumpulan data dilakukan melalui observasi, wawancara mendalam dan studi dokumentasi. Data dianalisis melalui perbandingan pernyataan dari sejumlah informan kunci. Populasi dalam penelitian ini adalah masyarakat Pandai Sikek yang terjun langsung dalam bidang inovasi dan pengembangan pengetahuan songket. Pengambilan sampel dilakukan dengan teknik snowball sampling yang dipilih satu orang pertama yang menjadi informan kunci. Jumlah informan kunci dalam penelitian ini sebanyak 6 orang yang merupakan rekomendasi dari informan kunci sebelumnya. Pengumpulan data dinyatakan cukup apabila informasi mengenai perubahan pengetahuan mengenai pembuatan songket yang dirasakan oleh beberapa narasumber sudah berulang.

\section{HASIL DAN PEMBAHASAN}

Banyaknya informasi yang tersedia dalam berbagai bentuk membuat manusia terus berkarya sehingga membutuhkan banyak informasi. Ketika informasi sudah menjadi kebutuhan maka masyarakat akan berubah dari masyarakat tradisional menjadi masyarakat informasi. Terdapat dua perspektif informasi secara umum yaitu informasi menjadi konten dan informasi suatu bahan media representasi informasi. Informasi mencakup segala aspek kehidupan masyarakat sehingga keberadaan informasi menjadi interdisiplin atau multidisciplinary yang berarti keberadaan informasi melintasi berbagai disiplin ilmu dengan berbagai media informasi serta memenuhi semua kebutuhan informasi. Informasi dapat menggantikan sumber daya yang dapat menyebar dan mengalami perubahan (Pijbers, 2010). Informasi adalah manusia, informasi ada karena persepsi manusia. Nilai informasi diberikan oleh manusia sebagai pengguna informasi serta bagaimana informasi yang sudah ada kemudian digunakan sebagai pengetahuan. Pengetahuan yang dilakukan secara terus menerus akan menghasilkan pengalaman. Adanya 
pengalaman diharapkan akan terciptanya inovasi untuk perkembangan masyarakat.

Komunikasi budaya adalah upaya mempertukarkan berbagai informasi mengenai pengetahuan masyarakat Pandai Sikek. Komunikasi yang ada dalam bentuk nilai dan norma masyarakat. Keterkaitan antara budaya dengan komunikasi tidak dapat terpisahkan. Sekelompok masyarakat menggunakan budaya dalam berkomunikasi, sedangkan komunikasi digunakan untuk keberlangsungan suatu kebudayaan. Menurut Mulyana (2010), budaya merupakan suatu pola hidup menyeluruh. Budaya menentukan bagaimana cara dan perilaku seseorang dalam komunikasi. Komunikasi budaya menghasilkan persepsi yang sama dalam suatu kebudayaan sehingga mereka memiliki keyakinan dan pandangan yang sama. Adanya komunikasi budaya menciptakan nilai dan norma kebudayaan yang dijadikan acuan hidup bagi masyarakat budaya.

Pada proses transformasi pengetahuan lokal di Pandai Sikek terdapat tiga elemen utama yang melakukan komunikasi sebagai agen peralihan masyarakat tradisional ke masyarakat informasi. Adapun elemen utama tersebut adalah penenun, pengusaha dan pemerintah. Komunikasi yang dilakukan penenun, pengusaha dan pemerintah merupakan penentu bagaimana transformasi pengetahuan lokal mengenai budaya tenun songket di Pandai Sikek terjadi. Komunikasi yang terjadi di antara mereka adalah komunikasi budaya yang memperlihatkan keterkaitan semua elemen yang terlibat dalam budaya songket di Nagari Pandai Sikek. Keberadaan nilai dan norma dalam masyarakat merupakan sebuah proteksi untuk melindungi mereka dari hal negatif yang berasal dari lingkungan luar budaya mereka. Hal lain terlihat apabila kebutuhan semakin mendesak dan mengalami ancaman maka akan terjadi krisis kebudayaan dan krisis nilai sehingga membutuhkan perubahan.

Komunikasi penenun dengan penenun merupakan hal utama dalam terjadinya proses transformasi pengetahuan lokal. Penenun di sini terdiri dari dua jenis yaitu peristiwa komunikasi yang terjadi antar penenun yang hidup dalam satu keluarga dan peristiwa komunikasi yang terjadi antar penenun yang tidak dalam satu keluarga. Komunikasi antar penenun yang hidup dalam satu keluarga cenderung sangat terbuka dalam hal membuat songket dan menghasilkan modifikasi terbaru. Pijbers (2010) juga mengemukakan bahwa informasi dapat menggantikan sumber daya yang dapat menyebar dan mengalami perubahan. Informasi adalah manusia, informasi ada karena persepsi manusia. Nilai informasi diberikan oleh manusia sebagai pengguna informasi serta bagaimana informasi yang sudah ada kemudian digunakan sebagai pengetahuan. Hal ini terlihat dari keterbukaan informasi apapun yang mereka dapatkan diberikan ke semua keluarga penenun. Hal ini terjadi karena biasanya penenun yang hidup dalam satu keluarga dan hidup dalam satu atap adalah ibu dan anak, kakak dan adik serta beberapa keluarga yang hidup dalam satu atap (seperti kakak adik yang sudah berkeluarga tapi tetap tinggal satu rumah). Pada penenun yang tinggal satu rumah terjadi keterbukaan informasi apapun yang mereka dapatkan dari lingkungan sekitar. Hal ini tidak ditemukan di komunikasi antar penenun yang tidak 
hidup dalam satu keluarga. Komunikasi antar penenun yang tidak hidup dalam satu keluarga dapat dikatakan sangat tertutup mengenai modifikasi motif.

Ketidakterbukaan akan modifikasi motif ini terjadi karena apabila satu orang membuat yang bagus maka yang lainnya akan membuat hal yang sama. Jika sesuatu yang bagus dibuat secara bersamaan maka kesan "bagus" nya pun juga akan hilang. Hal yang berbeda terlihat dari bagaimana mereka saling berbagi informasi mengenai teknologi yang dikembangkan oleh mereka sendiri dan Pusat Inovasi Songket Pandai Sikek. Pusat Inovasi Songket Pandai Sikek merupakan lembaga yang dibangun pemerintah Tanah Datar untuk pengembangan dan inovasi produk tenun songket Pandai Sikek. Keterbukaan mereka dalam menerima dan memberikan informasi yang berkaitan dengan teknologi berkaitan dengan kemudahan dan ketepatan dalam membuat songket. Komunikasi antar penenun merupakan komunikasi dasar yang dilakukan dalam melakukan transformasi pengetahuan mengenai budaya tenun. Pada dasarnya, mereka sengaja menyimpan pengetahuan yang mereka punya untuk mendapatkan harga jual yang cocok sesuai dengan keindahan yang ditawarkan. Hal ini terjadi karena semakin rumit pembuatan songket, maka semakin mahal pula harga yang ditawarkan. Pada proses ini terjadi enkulturasi di mana pembelajaran yang dilihat dari pengalaman seperti biasa dilakukan sehari-hari. Pengalaman yang dilihat disimpan dan diolah dalam bentuk informasi untuk kemudian dijadikan pengetahuan.

Hal yang berbeda terlihat dari bagaimana mereka saling berbagi informasi mengenai teknologi yang dikembangkan oleh mereka sendiri dan
Pusat Inovasi Songket Pandai Sikek. Keterbukaan mereka dalam menerima dan memberikan informasi yang berkaitan dengan teknologi berkaitan dengan kemudahan dan ketepatan dalam membuat songket. Realitas tersebut sesuai dengan yang dikemukakan Mascarenhas (2004) dalam Teffo (2011), adanya pengetahuan lokal merupakan pengetahuan yang tumbuh dan berkembang dalam kelompok sosial (masyarakat) dengan menggabungkan hasil pembelajaran (pengalaman) yang didapatkan dari generasi ke generasi dan sumber lainnya untuk kemudian terinternalisasikan dalam cara berpikir masyarakat lokal.

Komunikasi penenun dengan pengusaha adalah ujung tombak dari kelangsungan ekonomi masyarakat Pandai Sikek. Adapun komunikasi antara penenun dengan pengusaha selalu dilakukan secara langsung. Pengusaha secara langsung mendatangi penenun untuk kemudian disampaikan pesan berupa motif, harga dan perjanjian. Pertama, komunikasi yang mengandung pesan motif membicarakan masalah modifikasi motif dan motif yang paling diminati. Hal ini terlihat dari aktivitas yang dilakukan pengusaha dengan penenun ketika penenun mengatakan "ancak lo motifnyo yo" (bagus ya). Hal ini menunjukkan bahwa penenun secara tidak langsung melihat hasil kerja dari penenun lainnya di tempat pengusaha. Kemudian mereka menanggapi bagaimana indahnya hasil modifikasi. Hal ini juga didukung oleh Nakata dan Langton (2005) dalam Anyira, Onoriode, dan Nwabueze (2010) yang menyatakan bahwa pengetahuan lokal yang diciptakan masyarakat lokal dari waktu ke waktu mencakup teknologi, pengetahuan, keterampilan, praktik dan 
keyakinan yang membuat keadaan masyarakat menjadi stabil. Pada sisi lain pengusaha juga memperlihatkan motif tenun yang sudah dimodifikasi melalui foto di handphone mereka sebagai media penyimpanan motif baru. Kedua, komunikasi yang mengandung pesan harga dilakukan searah oleh pengusaha. Dalam hal ini pengusaha memiliki dua metode dalam membahas harga. Metode pertama, pengusaha memberitahukan harga dengan nama upah. Upah diberikan pengusaha apabila benang dimodali oleh pengusaha, sehingga penenun hanya menerima upah. Metode kedua, pengusaha memberikan harga kepada penenun yang membuat songket dengan biaya sendiri. Dalam hal ini pengusaha membeli songket yang dibuat penenun untuk kemudian dijual pada pengusaha. Ketiga, komunikasi yang terjalin antara penenun dengan pengusaha mengandung pesan perjanjian antara penenun dan pengusaha dilakukan untuk mengantisipasi konflik yang akan terjadi di masa yang akan datang. Konflik yang sering terjadi antara pengusaha dengan penenun yaitu mancilok anak tanun (mencuri anak tenun) di mana terjadi pencurian anak tenun oleh pengusaha lain. Pada kenyataannya ICT memang mengubah beberapa konten pengetahuan yang ada pada masyarakat lokal namun ICT dapat digunakan untuk mendukung dan mendorong budaya agar dapat dilestarikan dan dipromosikan oleh masyarakat lokal dengan menonjolkan identitas, pengetahuan lokal, bangsa serta suku yang ada dalam tatanan masyarakatnya. Pengetahuan lokal sangat memungkinkan terjadi perubahan karena adanya faktor lingkungan, keadaan ekonomi, politik dan budaya yang terjadi baik pada skala lokal maupun nasional (World Bank, 2011).

Hubungan yang terjalin antara penenun dengan pengusaha juga menentukan bagaimana hubungan pengusaha dengan pengusaha. Selain itu penenun melalui pengusaha juga sering kali berinteraksi dengan para pengusaha lainnya (di luar Pandai Sikek) untuk mengembangkan hasil tenunnya. Para pengusaha mengadakan sharing pengalaman dengan para penyulam, sehingga penenun pun mulai menggabungkan tenunan dengan hasil sulaman. Salah satu penyulam yakni di daerah Ngarai Sianok (Bukittinggi). Hasil tenun dan sulaman ini kemudian dipasarkan oleh pengusaha. Proses ini menandakan adanya perubahan di masyarakat lokal yang mulai berkomunikasi dengan masyarakat nonpribumi. Perubahan masyarakat melalui komunikasi terjadi karena beberapa hal sebagai berikut: (1) Proses difusi, di mana terjadinya penyebaran nilai dan kebiasaan pada masyarakat lokal. Biasanya proses difusi terjadi secara sengaja atau tidak sengaja. (2) Proses belajar kebudayaan sendiri, di mana masyarakat lokal selalu belajar menggunakan pengetahuan mereka melalui pengembangan sistem kebudayaan. Hasil belajar ini yang akan menghasilkan inovasi pada pengetahuan masyarakat.

Komunikasi penenun dengan pemerintah biasanya terjadi secara langsung. Komunikasi ini difasilitasi oleh kelompok penenun. Penenun menyampaikan pendapatnya pada kelompok penenun, kemudian kelompok memberikan pendapat tersebut pada Kantor Walinagari. Kemudian Kantor Walinagari memfasilitasi komunikasi 
dengan Dinas Koperasi, Perindustrian, Perdagangan, Pasar dan Pertambangan (KOPERINDAGPASTAM). Selain itu, kelompok penenun juga dapat menyampaikan pendapatnya pada Pusat Inovasi Tenun Songket Pandai Sikek untuk kemudian disampaikan pada Dinas KOPERINDAGPASTAM. Hasil dari komunikasi antara penenun dengan pemerintah adalah adanya Peraturan Nagari Pandai Sikek Nomor 3 Tahun 2006 tentang Tenun Antik Pandai Sikek. Secara umum perumusan peraturan Nagari ini mengatur segala hal yang berkaitan dengan budaya tenun Pandai Sikek. Adapun isi dari peraturan Nagari ini adalah ketentuan kepemilikan pengetahuan tenun Pandai Sikek, Kelembagaan Tenun, Penyediaan Bahan Baku dan Pemasaran, Iklim Usaha Yang Sehat, Pelestarian Tenun, Larangan dan Sanksi, dan Prosedur Penyelesaian Masalah. Menurut United Nation (2013) menyatakan bahwa masyarakat lokal merupakan bagian dari masyarakat nondominan yang memiliki tekad untuk melestarikan, mengembangkan dan mentransmisikan ke generasi selanjutnya sesuai dengan pola budaya, sosial, lembaga dan sistem hukum yang berlaku. Pengetahuan ini menjadi landasan dalam pengambilan keputusan pada aspek fundamental masyarakat. Adapun dalam praktiknya secara umum pengetahuan lokal memiliki tiga klasifikasi utama seperti yang diungkapkan oleh Grenier dalam UNESCO (2010) sebagai berikut: (a) Learning systems, berkaitan dengan metode yang digunakan masyarakat lokal dalam menyampaikan pengetahuan dalam bentuk pendekatan psikologi, inovasi, eksperimen, permainan serta metode pembelajaran lainnya. (b) Local organizations, controls, and enforcement, berkaitan dengan lembaga tradisional (local institutional) dalam melakukan manajemen lingkungan, manajemen kepemimpinan, pengambilan keputusan, manajemen konflik, hukum, taboo serta pengontrolan masyarakat oleh lembaga adat. (c) Local classification and quantification, berkaitan dengan bagaimana masyarakat mendefinisikan serta mengklasifikasikan fenomena alam, flora dan fauna serta metode tradisional dalam menghitung dan mengukur.

Untuk

melaksanakan

keberlangsungan profesi penenun maka dibuat Keputusan Walinagari Pandai Sikek No 13/KPTS/WN-PS/2012 tentang pembentukan kelompok pengrajin songket Pandai Sikek. Kelompok ini didirikan untuk setiap jorong/dusun yang ada di Pandai Sikek. Pembentukan kelompok memang sudah dikatakan pada Peraturan Nagari bahwa, Kantor Walinagari akan memfasilitasi kelompok profesi secara hukum (Pemerintah Nagari Pandai Sikek, 2012).

Hasil dari komunikasi penenun, pengusaha dan pemerintah selanjutnya adalah Keputusan Walinagari Pandai Sikek Nomor 7 tahun 2009 Tentang Pengangkatan Panitia Inventaris dan Pendaftaran Perlindungan Hukum Hak Kekayaan Intelektual (HAKI) Kerajinan Tradisional Tenun Antik Pandai Sikek (Pemerintah Nagari Pandai Sikek, 2009). Pendaftaran ini dilakukan untuk upaya pelestarian dan perlindungan hukum tenun Pandai Sikek. Upaya ini dilakukan sebagai bentuk perjuangan untuk mendapatkan pengakuan bahwa tenun Pandai Sikek adalah milik anak nagari Pandai Sikek

Pada pendaftaran ini dilakukan dua pendaftaran utama yaitu pendaftaran Hak Kekayaan Intelektual terhadap motif. 
Pendaftaran ini dilakukan pada tanggal 27 Juli 2009. Sedangkan untuk pendaftaran Hak Merk sudah dilakukan sejak 29 Oktober 2008. Kemudian pada tanggal 28 Juni 2010 nomor pendaftaran Hak Kekayaan Intelektual untuk motif Pandai Sikek resmi dikeluarkan. Motif tradisional Pandai Sikek yang diakui pada saat itu sejumlah 25 motif. Sedangkan untuk Hak Merk Pandai Sikek mengalami penolakan, karena menurut surat Kementerian Hukum dan Hak Asas Manusia RI pada surat Nomor HKI. 4. 01. 15. 2008040214, bahwa Pandai Sikek yang diajukan adalah milik umum sehingga tidak dapat dilakukan klaim untuk nama. Untuk menanggapi hal tersebut, pemerintah dalam hal ini Kantor Walinagari mengajukan keberatan terhadap pemberitahuan penolakan pendaftaran merk. Dalam pengajuan keberatan ini dikatakan bahwa yang dimaksud dengan merk Pandai Sikek bukan secara geografis atau nama tempat, melainkan nama untuk merk dagang tenun Pandai Sikek. Masyarakat Pandai Sikek sebagai pemilik pengetahuan tenun Pandai Sikek ini merasa berhak diakui secara hukum.

Pada masyarakat Pandai Sikek, komunikasi yang terjadi antara penenun, pengusaha dan pemerintah. Terdapat peran pada masing-masing komponen yang mendorong terjadinya transformasi pengetahuan. Penenun, pengusaha dan pemerintah melakukan komunikasi yang menciptakan nilai dan norma yang kemudian dijadikan panduan dalam masyarakat. Penciptaan nilai dan norma dalam satu kebudayaan seperti ini merupakan peristiwa komunikasi budaya (Mulyana, 2010). Masyarakat dalam hal ini menciptakan nilai dan norma melalui interaksi yang mereka lakukan.
Komunikasi yang terjadi pada penenun, pengusaha dan pemerintah dalam hal ini melakukan proses belajar kebudayaan mereka sendiri. Proses belajar akan menghasilkan pengalaman dan pengetahuan bagi masyarakat. Pada komunikasi antar penenun yang melibatkan pengetahuan lokal mengenai budaya tenun songket terjadi sharing information yang bersifat partisipatif. Di mana pada proses komunikasi tidak dapat mengidentifikasi sender dan receiver. Hal ini terjadi karena setiap orang dalam masyarakat dapat menjadi pencipta pengetahuan dan dapat menginformasikan secara langsung. Sharing information yang bersifat partisipatif terjadi pada proses komunikasi penenun dalam keluarga, kelompok serta institusi pendukung, dalam hal ini adalah Pusat Inovasi Songket Pandai Sikek. Individu penenun dalam hal ini memiliki persepsi dan interpretasi terhadap informasi yang dibagikan dan didiskusikan dalam keluarga dan kelompok. Adanya sharing information tanpa terlihat jelas pengirim dan penerima pesan (Amar, 2010). Selain itu jika ditinjau dari bentuk komunikasi yang terjadi antar penenun merupakan komunikasi horizontal. Di mana semua partisipan dalam kegiatan komunikasi yang dilakukan dianggap setara dan memiliki tujuan yang sama. Namun adanya komunikasi yang bersifat horizontal ini juga terhalang anggapan bahwa yang nan tuo tuo memiliki pengetahuan baku sehingga sulit untuk menerima informasi yang berkaitan dengan teknologi. Hal ini terjadi karena adanya perbedaan makna antik bagi nan tuo tuo dengan nan mudomudo. Antik bagi nan tuo-tuo adalah semua motif, teknologi, dan teknik 
dilakukan secara manual dan tradisional, sedangkan bagi nan mudo-mudo antik di sini merupakan menghasilkan songket yang berkualitas sama dengan tetap memerhatikan nilai budaya, namun dapat mengefektifkan waktu. Komunikasi antar penenun jika digambarkan akan berbentuk siklus yang melibatkan pengalaman, sharing information, proses pengaplikasian, kemudian menjadi pengetahuan. Pengetahuan yang dimiliki jika terus dikembangkan akan menghasilkan inovasi.

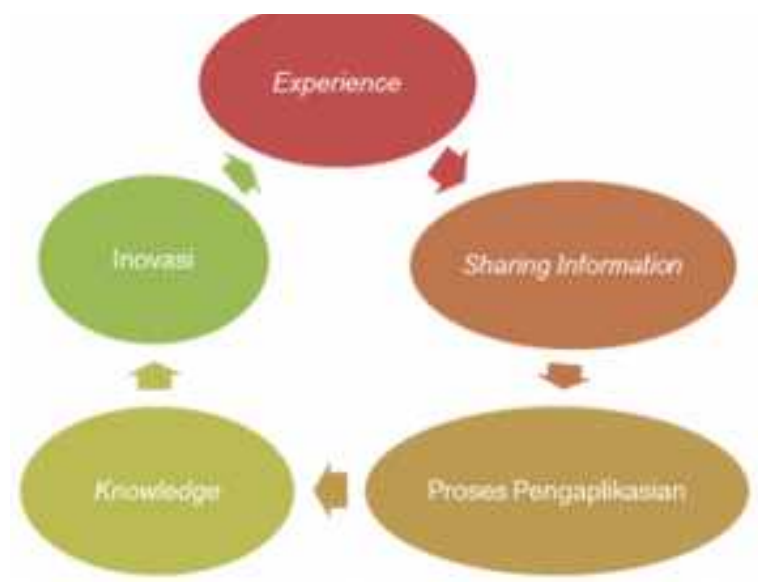

Gambar 1. Pola hubungan antar penenun Sumber: Hasil Penelitian, 2015

Melalui proses interaksi antar penenun, pengusaha dan pemerintah menunjukkan bahwa hal ini menjadi salah satu perkembangan inovasi dan teknologi. Interaksi yang terjadi dalam masyarakat baik dalam maupun dengan lingkungan sekitar Pandai Sikek menunjukkan bahwa kedinamisan masyarakat dalam menerima informasi, meskipun kedinamisan ini akan berakibat pada terjadinya beberapa modifikasi dan penemuan pada pengetahuan lokal mereka. Pembaharuan atau inovasi ini mendukung terjadinya discovery. Yakni banyaknya penemuan hasil kebudayaan tenun songket dan menjadi pengembangan gagasan dari masyarakat secara bersama-sama. Hal ini pula yang mendorong terjadinya proses invention. Pemerintah melakukan penindaklanjutan akan pengembangan pengetahuan lokal serta untuk melestarikan melalui pendaftaran dalam bentuk pengakuan. Pengakuan yang dibuat oleh masyarakat Pandai Sikek ini dapat dilihat dari adanya Peraturan Nagari Pandai Sikek yang berisikan aturan mengenai pengetahuan dan industri tenun, serta adanya pendaftaran hak cipta dan hak merk dagang di Kementerian Hukum dan Hak Asasi Manusia pada tahun 2009.

Unsur komunikasi yang terjadi pada masyarakat yang dilihat dari penenun, pengusaha dan pemerintah terdapat peran yang dapat dikatakan sangat penting namun tidak ada, yaitu arsip dan perpustakaan sebagai pusat dokumentasi dan informasi mengenai pengetahuan lokal dalam satu daerah. Keberadaan perpustakaan sebagai unsur penting dalam pengetahuan lokal bahwa perpustakaan melaksanakan program untuk mengumpulkan, melestarikan dan menyebarkan pengetahuan lokal (International Federation of Library Associations and Institutions., 2008). Berdasarkan hasil penelitian yang penulis dapatkan, mengumpulkan pengetahuan lokal dilakukan oleh pemerintah Pandai Sikek yang kontennya masih sangat terbatas pada teknologi dan motif. Pusat Inovasi Tenun Songket Pandai Sikek hanya melakukan pelestarian pengetahuan dilakukan oleh anggota, dan belum melakukan penyebarluasan informasi mengenai pengembangan pengetahuan lokal Pandai Sikek. Penyebarluasan informasi diperlukan masyarakat Pandai Sikek sendiri dan masyarakat di luar untuk menjamin keberlangsungan kegiatan budaya ini. 


\section{SIMPULAN}

Adanya proses transformasi pengetahuan lokal masyarakat tidak lepas dari adanya komunikasi budaya yang dilakukan oleh komponen masyarakat yang secara aktif terlibat langsung dalam budaya songket di Pandai Sikek, yaitu penenun, pengusaha dan pemerintah. Penenun, pengusaha dan pemerintah melakukan komunikasi yang menciptakan nilai dan norma yang kemudian dijadikan panduan dalam masyarakat. Di mana masyarakat secara sadar mampu membedakan nilai tradisional dan pengembangan modern yang mereka lakukan melalui proses komunikasi yang terjadi dalam masyarakat. Komunikasi yang terjadi pada penenun, pengusaha dan pemerintah dalam hal ini melakukan proses belajar kebudayaan mereka sendiri. Pada komunikasi antar penenun yang melibatkan pengetahuan lokal mengenai budaya tenun songket terjadi sharing information yang bersifat partisipatif. Interaksi yang terjadi dalam masyarakat baik dalam maupun dengan lingkungan sekitar Pandai Sikek menunjukkan bahwa kedinamisan masyarakat dalam menerima informasi, meskipun kedinamisan ini akan berakibat pada terjadinya beberapa modifikasi dan penemuan pada pengetahuan lokal mereka. Selain itu komunikasi antara penenun dengan pengusaha mengandung pesan yang berupa motif, harga dan perjanjian. Kesepakatan keduanya akan berdampak pada kegiatan ekonomi masyarakat. Kesepakatan ini dilanjutkan dengan komunikasi penenun dan pemerintah yang menghasilkan pendaftaran Hak Kekayaan Intelektual. Namun, dalam proses ini belum adanya keterlibatan perpustakaan dan arsip dalam mendokumentasikan pengetahuan menjadi salah satu kesulitan dalam mengumpulkan informasi mengenai sejarah dan pengembangan pengetahuan. Untuk selanjutnya diharapkan partisipasi aktif dari Badan Perpustakaan dan Arsip Daerah untuk mendokumentasikan hasil kegiatan masyarakat sebagai wujud pelestarian pengetahuan lokal masyarakat.

\section{DAFTAR PUSTAKA}

Amar, S. C. D. (2010). Gunem catur in the Sunda region of West Java: indigenous communication on the mac plant knowledge and practice within the arisan in Lembang, Indonesia (Disertation). Leiden University, Netherlands.

Anyira, I.; Onoriode, O. K. \& Nwabueze, A. (2010). The role of libraries in the preservation and accessibility of indigenous knowledge in the Niger Delta Region of Nigeria. Library Philosophy and Practice, 387(6), 1-9. Retrieved from https:/ / digitalcommons.unl.edu/cgi/ viewcontent.cgi?referer=http:/ / digital commons.unl.edu/cgi/viewcontent.cg i? article $=1400 \&$ context $=$ libphilprac\&ht tpsredir $=1 \&$ article $=1400 \&$ context $=$ libp hilprac

Creswell, J. W. \& Poth, C. N. (2012). Qualitative inquiry $\mathcal{E}$ research design: choosing among five approach (4th ed.). London: Sage.

Erza, E. K. (2014). Transfer pengetahuan manyongket pada tradisi masyarakat Pandai Sikek (Skripsi). Universitas Padjadjaran, Sumedang.

International Federation of Library Associations and Institutions. (2008). IFLA statement on indigenous traditional knowledge. Retrieved from https://www.ifla.org/publications/ifl a-statement-on-indigenous-traditionalknowledge

Mulyana, D. (2010). Komunikasi antarbudaya: panduan berkomunikasi dengan orang-orang berbeda budaya. Bandung: Remaja Rosda Karya. 
Nath, H. K. (2009). The information society. A Journal of The SCTU, 4(1), 19-29.

https://doi.org/https://doi.org/10.1 109/TDEI.2009.5211872

Pemerintah Nagari Pandai Sikek. (2009). Pengangkatan panitia inventaris dan pendaftaran perlindungan hukum hak kekayaan intelektual (HAKI) kerajinan tradisional tenun antik Pandai Sikek, Pub. L. No. Keputusan Walinagari Pandai Sikek Nomor 7. Indonesia: Pemerintah Nagari Pandai Sikek.

Pemerintah Nagari Pandai Sikek. (2012). Pembentukan kelompok pengrajin songket Pandai Sikek, Pub. L. No. Keputusan Walinagari Pandai Sikek No 13/KPTS/WN-PS/2012. Indonesia: Pemerintah Nagari Pandai Sikek.

Pijbers, G. (2010). Information overload: A system for better managing everyday data. New Jersey: John Wiley \& Sons.

Primadesi, Y. (2013). Preservasi pengetahuan dalam tradisi lisan seni pertunjukan randai di Minangkabau Sumatera Barat. Jurnal Kajian Informasi Dan Perpustakaan, 1(2), 179-187. https://doi.org/https://doi.org/10.2 4198/jkip.v1i2.12060.g5618
Teffo, L. (2011). Epistemic pluralism for knowledge transformation. Journal of African Renaissance Studies, 6(1), 24-34.

Retrieved

from https://www.tandfonline.com/doi/a bs/10.1080/18186874.2011.592388

UNESCO. (2010). Module 11: Indigenous knowledge \& sustainability. In Integration of groundwater management into transboundary basin organizations in Africa - a training manual by AGW-Net, BGR, IWMI, CapNet, ANBO, E IGRAC (pp. 1-44). Paris: UNESCO.

United Nation. (2013). The United Nations declaration on the rights of indigenous peoples. Sydney: United Nations High Commissioner For Human Rights. Retrieved from http://www.un.org/esa/socdev/unp fii/documents/DRIPS_en.pdf

WIPO. (2014). Intergovernmental Committee on Intellectual Property and Genetic Resources, traditional knowledge and folklore. Geneva: WIPO.

World Bank. (2011). The State of World Bank knowledge services: knowledge for development. Washington: Communications Development Incorporated. 
